\title{
Assessment of the Effectiveness of the European Union Countries Transition to a Circular Economy: Data Envelopment Analysis
}

\author{
Zhansaya S. Temerbulatova ${ }^{1}$, Aknur Zhidebekkyzy ${ }^{1 *}$, Monika Grabowska ${ }^{2}$ \\ ${ }^{1}$ Al-Farabi Kazakh National University, 71 al-Farabi ave., 050040, Almaty, Kazakhstan, \\ ${ }^{2}$ Wroclaw University of Economics and Business, Wroclaw, Poland
}

\begin{abstract}
In the current era of overconsumption, transition to circular economy is a relevant problem for every country in the world. The main idea behind this economic approach is to break the link between rising wealth and overexploitation of primary natural resources. The article assessed the current and future state of the circular economy's development in 27 countries of the European Union. The assessment was carried out using Data Envelopment Analysis based on data for 2019 of selected input and output parameters described by the circular economy. Generation of municipal waste per capita, Water exploitation index, Final energy consumption and Social Progress Index were used as input parameters. Circular material use rate and municipal waste recycling rate were output parameters. All data was collected from official reliable sources such as Eurostat, and the Social Progress Imperative website. The study results showed that as of $2019,40,74 \%$ of European countries have high efficiency in the advancement of circular economy, $40,74 \%$ - sufficient, $11,11 \%$ - medium and $7.41 \%$ - low efficiency. However, the analysis showed very good prospects for the future progress of the circular economy in these countries, since the overall efficiency results in the CCR model range from 0.899 to 1 for all countries in the European Union. With the implementation of the New Circular Economy Action Plan, which was adopted in 2020 by the European Commission, the EU countries have the opportunity to fully turn to the circular economy and ensure the healthy, sustainable development of countries.
\end{abstract}

Keywords: circular economy, European Union, Data Envelopment Analysis, municipal waste, recycling, consumption, efficiency.

For citation: Zhansaya, S.T., Zhidebekkyzy, A. \& Grabowska, M. (2021). Assessment of the Effectiveness of the European Union Countries Transition to a Circular Economy: Data Envelopment Analysis. Economics: the Strategy and Practice, 16(3), 142-151, https://doi.org/10.51176/1997-9967-2021-3-142-151

* Corresponding author: Zhidebekkyzy Aknur - PhD, Associate Professor, Kazakh National University, 050040, Almaty, Al-Farabi avenue 71, Kazakhstan, 8776007 2077, e-mail: aknur.zh@gmail.com

Conflict of interests: the authors declare that there is no conflict of interest.

Financial support: This research was funded by the Science Committee of the Ministry of Education and Science of the Republic of Kazakhstan (Grant No. AP09259851).

The article received: 16.06 .2021

The article approved for publication: 23.06 .2021

Date of publication: 30.09 .2021 


\title{
Еуропалық одақтың циркулярлы экономикаға көшу тиімділігін бағалау: жұмыс ортасын талдау
}

\author{
Темербулатова Ж.С. ${ }^{1}$ Жидебекқызы А. ${ }^{*}$, Грабовска М.ㄹ, \\ ${ }^{1}$ әл-Фараби атындагы Қазақ ұлттық университеті, әл-Фараби д., 71, \\ 050040, Алматы к̧.,Қазақсстан, \\ ${ }^{2}$ Вроилав экономика және бизнес университеті, Вроилав к., Польша
}

\begin{abstract}
Түйін
Қазіргі шамадан тыс тұтыну дәуірінде циркулярлы экономикаға көшу әлемнің әр елі үшін өзекті мәселе болып табылады. Бұл экономикалық көзқарастың негізгі идеясы - байлықтың өсуі мен негізгі табиғи ресурстарды шамадан тыс пайдалану арасындағы байланысты үзу. Мақалада Еуропалық Одақтың 27 еліндегі циркулярлы экономиканың ағымдағы және болашақ даму жағдайына баға берілді. Бағалау циркулярлы экономиканың дамуын сипаттайтын таңдалған кіріс және шығыс параметрлерінің 2019 жылғы деректері негізінде жұмыс ортасын талдау (DEA) әдісін қолдану арқылы жүргізілді. Жұмыс ортасын талдау шеңберінде CCR және BCC модельдері бағаланды. Кіріс параметрлері ретінде жан басына шаққандағы коммуналдық қалдықтардың пайда болуы, суды пайдалану индексі, энергияны түпкілікті тұтыну және әлеуметтік прогресс индексі анықталды. Ал шығыс параметрлері циркулярлы материалды пайдалану үлесі, коммуналдық қалдықтарды өңдеу деңгейі болды. Барлық деректер Еуростат және Social Progress Imperative веб-сайты сияқты ресми сенімді дереккөздерден жиналды. Зерттеу нәтижелері 2019 жылғы жағдай бойынша Еуропалық Одақ елдерінің 40,74\%-ы циркулярлы экономиканы дамытудың жоғары тиімділігіне, 40,74\% жеткілікті, $11,11 \%$ - орташа және 7,41\% - төмен тиімділікке ие екенін көрсетті. Алайда, талдау осы елдерде циркулярлы экономиканың болашақ дамуына өте жақсы перспективалар көрсетті, CCR үлгісіндегі жалпы өнімділік нәтижелері Еуропалық Одақтың барлық елдері үшін 0,899-нан 1-ге дейін. Еуропалық комиссия 2020 жылы қабылдаған циркулярлы экономика жөніндегі жаңа іс-қимыл жоспарын жүзеге асыру кезінде Еуроодақ елдерінің циркулярлы экономикаға толық көшуге және елдердің салауатты, тұрақты дамуын қамтамасыз етуге мүмкіндіктері бар.
\end{abstract}

Түйін сөздер: циркулярлы экономика, Еуропалық одақ, жұмыс ортасын талдау, коммуналдық қалдықтар, қайта өңдеу, тұтыну, тиімділік.

Дәйексөз алу үшін: Темербулатова Ж.С., Жидебекқызы А., Грабовска М. (2021). Еуропалық одақтың циркулярлы экономикаға көшу тиімділігін бағалау: жұмыс ортасын талдау. Экономика: стратегия және практика, 16(3), 142-151, https://doi.org/10.51176/1997-9967-2021-3-142-151

* Хат-хабаршы авторы: Жидебекқызы А. - PhD докторы, қауымдастырылған профессор, әл-Фараби атындағы Қазақ ұлттық университеті, 050040, Алматы қ., әл-Фараби даңғылы, 71, Қазақстан, +87760072077, e-mail: aknur.zh@gmail.com.

Мүдделер қақтығысы: авторлар мүдделер қақтығысының жоқтығын мәлімдейді.

Қаржыландыру. Аталған зерттеуді Қазақстан Республикасы Білім және ғылым министрлігінің Ғылым комитеті қаржыландырды (№ грант. АР09259851).

Мақала редакцияға түсті: 16.06 .2021

Жариялау туралы шешім қабылданды: 23.06 .2021

Жарияланды: 30.09 .2021 


\title{
Оценка эффективности перехода Европейского Союза к циркулярной экономике: анализ среды функционирования
}

\author{
Темербулатова Ж.С. ${ }^{1}$ Ж Жидбекқызы А. ${ }^{*}$, Грабовска М. \\ ${ }^{1}$ КазНУ имени аль-Фараби, пр. аль-Фараби 71, 050040, г. Алматы, Казахстан, \\ ${ }^{2}$ Университет экономики и бизнеса, г. Вроилав, Польша
}

\begin{abstract}
Аннотация
В нынешнюю эпоху сверхпотребления переход к циркулярной экономике является актуальным вопросом для каждой страны мира. Основной идеей такого экономического подхода является разрыв связи между растущим благосостоянием и чрезмерной эксплуатацией первичных природных ресурсов. В статье проведена оценка текущего и будущего состояния развития циркулярной экономики в 27 странах Европейского союза. Оценка была проведена с использованием метода Анализ среды функционирования (DEA) на основе данных за 2019 год отобранных входных и выходных параметров, описывающих развитие циркулярной экономики. В рамках анализа среды функционирования были оценены CCR и BCC модели. В качестве входных параметров были определены образование муниципальных отходов на душу населения, индекс использования воды, конечное потребление энергии, индекс социального прогресса. А выходными параметрами были доля использования циркулярного материала, уровень переработки муниципальных отходов. Bce данные были собраны с официальных достоверных источников, таких как Евростат и веб-сайта Social Progress Imperative. Результаты исследования показали, что по состоянию на 2019 год 40,74\% стран Европейского союза обладают высокой эффективностью развития циркулярной экономики, 40,74\% - достаточной, $11,11 \%$ - средней и 7,41\% - низкой эффективностью. Однако, анализ показал очень хорошие перспективы на будущее развитие циркулярной экономики в этих странах, поскольку результаты общей эффективности в CCR модели варьируются от 0,899 до 1 для всех стран Европейского союза. При осуществлении Нового плана действий по циркулярной экономике, который был принят в 2020 году Европейской комиссией, страны Евросоюза имеют возможность полностью перейти на циркулярную экономику и обеспечить здоровое, устойчивое развитие стран.
\end{abstract}

Ключевые слова: циркулярная экономика, Европейский союз, анализ среды функционирования, муниципальные отходы, переработка, потребление, эффективность.

Для цитирования: Темербулатова Ж.С., Жидебекқызы А., Грабовска М. (2021). Оценка эффективности перехода Европейского Союза к циркулярной экономике: анализ среды функционирования. Экономика: стратегия и практика, 16(3), 142-151, https://doi.org/10.51176/1997-9967-2021-3-142-151

* Корреспондирующий автор: Жидебекқызы А. - PhD, ассоциированный профессор, КазНУ им. альФараби, 050040, г. Алматы, пр. аль-Фараби 71, Казахстан, +87760072077, e-mail: aknur.zh@gmail.com

Конфликт интересов: авторы заявляют об отсутствии конфликта интересов.

Финансирование. Данное исследование было профинансировано Комитетом по науке Министерства образования и науки Республики Казахстан (грант №. АР09259851).

Статья поступила в редакцию: 16.06 .2021

Принято решение о публикации: 23.06 .2021

Опубликовано: 30.09.2021

144 Экономика: стратегия и практика. Т. 16, № 3, 2021 / Economics: the strategy and practice Vol. 16. No 3, 2021 


\section{Introduction}

The main problem of the economy is to meet the unlimited needs of people in conditions of limited resources. Over the past decades, there has been a trend towards overconsumption. At this rate, global consumption of materials such as fossil fuels, biomass, minerals, and metals is expected to double over the next 40 years, with annual waste generation expected to increase by $70 \%$ by 2050 . The emerging global problem reflects the relevance of the progress towards the circular economy (CE). The circular economy paradigm promotes rethinking and restructuring of the process of production, use, and disposal of products and services in the economy. The essence of circular economy is to achieve a decoupling effect between economic growth and resource use, also "transition towards a regenerative growth model that gives back to the planet more than it takes, advance towards keeping its resource consumption within planetary boundaries, and therefore strive to reduce its consumption footprint" [1].

The term circular economy was first coined in the study by Pearce and Turner in 1990, which emphasizes the relationship between economy and environment, with the $\mathrm{CE}$ concept as a sustainable alternative to the conventional linear take-makeuse-dispose model and replaces it with make-usereuse-remake-recycle [2].

In promoting the concept of circularity, the European Union (EU) has been a pioneer, as its member states have collectively initiated a series of policies and frameworks that promote $\mathrm{CE}$ in various industries, businesse,s and services. The concept has been widely researched and implemented in many countries of the world since the adoption of the action plan for a circular economy by the European Commission in 2015. This action plan presented ambitious targets for transforming the EU economy into a circular economy in which the cost of products and materials persists for as long as possible, thereby bringing great economic benefits along with social and environmental incentives [3]. In 2020, the European Commission adopted a new circular action plan that paves the way for a cleaner and more competitive Europe. The new plan clearly outlines the processes of developing circular products, promoting a sharing economy, preventing waste generation, and reusing resources. It also introduces legislative and non-legislative measures aimed at areas in which actions at the EU level bring real added value [1].

The research aim is to assess the status quo of the circular economy's development in the 27 countries of the EU and identify future trends. 27 EU countries were taken as the research object. The EU is currently leading the way towards a circular economy at the global level and will continue to use its experience, financial and organizational advantages to achieve the Sustainable Development Goals (SDGs), as global transformational change cannot be achieved alone.

The structure of the paper is as follows: the first section is an introduction that describes the relevance of the circular economy and the purpose of the article, the second section reviews the literature on previous research studies of the circularity in the European Union, the third section presents the Data Envelopment Analysis (DEA) methodology and the data used for analysis, the fourth section is the results and discussion, and the last section is a conclusion.

\section{Literature Review}

In recent years, a circular economy has become a popular research topic not only in the European Union but also in many developed and developing countries of the world.

Mhatre et al. conducted a systematic literature review of circular economy initiatives at the micro and macro levels in the EU and concluded that macro-level initiatives by governments and regional administrations prevail in the $\mathrm{CE}$ implementation [4].

In the study, Friant et al. defined the "circular economy" as an "irreversible global mega-trend" and examine the policies of the governments of the EU member states in advancing the circular economy. The authors concluded that the circular economy is a contested paradigm for which there were many competing interpretations, each of which tends to a different degree of social, environmental, and political transformation, so the policies applied in one country did not fit in another [5].

Policy actions and state measures for converting to towards a circular economy, their expectations, barriers and achievements were also explored by Hartley et al. [6], Kirchherr et al. [7], Momete [8], Marco-Fondevila et al. [9] and others.

When studying the elaboration of the "circular economy" concept in the EU, the method of bibliometric analysis of publications in the Web of Science and Scopus databases is also widely used $[10,11,12]$.

Quantitative methods for assessing the performance of $\mathrm{CE}$ are used in the following studies. Awasthi et al. used regression models for modelling the relation between waste quantities and economic development, results of the study revealed the presence of a strong linear correlation among them [13]. Also, one of the most frequent methodology Life Cycle Assessment (LCA) was proposed by Hadzic et al. as an assessment tool of wastes in urban contexts of Croatia [14]. Similar assessment was recurred by Martin et al. for Sweden [15]. 
In the study of Exposito and Velasco, DEA method was used to assess development's efficiency of regional recycling markets of Spain [16]. Voskamp et al. also recurred input-output analysis, but material flow analysis (MFA) approach for a complex evaluation of the urban metabolism of Amsterdam. As results show, Amsterdam's metabolism was dominated by portrelated throughput of fossil fuels and water flows [17].

During the literature review, it was noted that there is a research gap: a small number of studies use quantitative methods for the assessment of CE implementation effectiveness.

\section{Methodology}

Circular economy is a very broad concept with many indicators to assess its effectiveness in implementation. When evaluating effectiveness, it is important to correctly define the input and output parameters. The study uses the DEA method because it surveys both input and output data, seeking the places with the minimum input for the largest output employing the selected parameters, and linking the places to shape the frontier of efficiency. Each object could get a coefficient which shows its efficiency relatively. Therefore, in this study, we use DEA to evaluate circular economy development levels of $27 \mathrm{EU}$ countries.

DEA has been widely applied to assess the relative efficiency of a series of production units since 1978 [18]. It is a nonparametric statistical approach, and it need not determine the weights artificially and subjectively. It can not only judge whether decision-making units (DMUs) are relatively effective, but also can forecast future trends of development.

There are two models of DEA: CCR model (1) [18] and BCC model (2) [19].

$$
\min _{\eta_{C}}
$$

Subject to

$$
\begin{gathered}
\eta_{C} i_{0}-I_{\omega}-v^{-}=0, \\
O_{\omega}-v^{+}=o_{0}, \\
\omega \geq 0, v^{-} \geq 0, v^{+} \geq 0,
\end{gathered}
$$

" $\eta_{C}$ - the input-output efficiency of $D M U_{0}$ in CCR model;

$I$ - the input matrix;

$O$ - the output matrix;

$\omega$-a 27-dimensional weight vector;

$i_{0}$ - the input vector of $D M U_{0}$;

$o_{0}-$ the output vector of $D M U_{0}$;

$v^{-}$- input slack variable vector;

$v^{+}$- output slack variable vector" [19].
Where, and equals 1 only when both input and output slack vectors are zero and the inputs of are not more than any linear combination of other DMUs [20].

$$
\min _{\eta_{B}}
$$

"Subject to

$$
\begin{gathered}
\eta_{B} i_{0}-I_{\omega}-v^{-}=0 \\
O_{\omega}-v^{+}=o_{0} \\
e \omega=1 \\
\omega \geq 0, v^{-} \geq 0, v^{+} \geq 0
\end{gathered}
$$

$e-$ a 27-dimensional unit vector

$\eta_{\mathrm{B}}$ - the efficiency of in BCC model, . Where, other symbols represent the same signification as in (1)" "[20].

For Data Envelopment Anaysis, input and output indicators were selected that reflect the circular economy's development at the macro level (Table 1).

Data of all countries were collected for 2019. When choosing indicators, first of all, attention was paid to the scientific nature, rationality and availability of data. The sources from which the data were collected can guarantee the reliability and validity of the data.

The results of the $27 \mathrm{EU}$ countries under the $\mathrm{CCR}$ and $\mathrm{BCC}$ models are listed in Table 3. Overall efficiency $(\mathrm{OE})$ is the total efficiency in CCR, meaning the circular economy development level both in current and future scale. Pure technical efficiency (PTE) is the efficiency in BCC, indicating the current circular economy development level. Finally, scale efficiency (SE) is the ratio of PTE to $\mathrm{OE}$, which represents the trend of CE development level with the increase of developing scale.

Efficiency in the BCC model of DEA of 27 EU countries, which reflects the current situation of the development of CE in the countries, is clearly shown in Figure 1. Based on the results obtained, all countries are divided into 4 categories: countries with high $(0,9-1)$, sufficient $(0,6-0,899)$, medium $(0,4-0,599)$ and low $(0-0,399)$ efficiency of the circular economy development.

The best performance of CE was showed by Austria, Belgium, Germany, Luxembourg, Malta, Netherlands, Slovakia, Slovenia, Estonia, Latvia, Lithuania. It means that $40,74 \%$ of all countries have high efficiency of CE development, and countries with sufficient level of efficiency account for also $40,74 \%$. The remaining $18,52 \%$ are accounted for by countries with medium and low efficiency of CE development, $11,11 \%$ and $7,41 \%$, respectively. 
Table 1 - Input and output indicators in the DEA model

\begin{tabular}{|c|c|c|c|}
\hline Category & Indicator & Description & Source \\
\hline \multirow[t]{4}{*}{ Input } & $\begin{array}{l}\text { Generation of municipal } \\
\text { waste per capita, kg per } \\
\text { capita }\end{array}$ & $\begin{array}{l}\text { "The indicator measures the waste collected by or on } \\
\text { behalf of municipal authorities and disposed of through } \\
\text { the waste management system. It consists to a large } \\
\text { extent of waste generated by households, though similar } \\
\text { wastes from sources such as commerce, offices and public } \\
\text { institutions may be included" [21] }\end{array}$ & Eurostat \\
\hline & Water exploitation index & $\begin{array}{l}\text { "It quantifies how much water is abstracted and how much } \\
\text { water is returned after use to the environment" [21] }\end{array}$ & Eurostat \\
\hline & $\begin{array}{l}\text { Final energy consumption, } \\
\text { million tons of oil } \\
\text { equivalent }\end{array}$ & $\begin{array}{l}\text { "It is meant all energy supplied to industry, transport, } \\
\text { households, services and agriculture" }\end{array}$ & Eurostat \\
\hline & $\begin{array}{l}\text { Social Progress Index } \\
\text { (SPI) }\end{array}$ & $\begin{array}{l}\text { "The basic blocks of the index reflect the degree, to which } \\
\text { a society is able to cover the needs of its members, creates } \\
\text { an environment in which citizens can improve their life } \\
\text { quality and provides enough opportunities for individuals } \\
\text { to advance to their full potential, respecting their choices } \\
\text { and freedom" [22] }\end{array}$ & $\begin{array}{l}\text { Social } \\
\text { Progress } \\
\text { Imperative } \\
\text { website }\end{array}$ \\
\hline \multirow[t]{2}{*}{ Output } & $\begin{array}{l}\text { Circular material use rate, } \\
\% \text { of total material use }\end{array}$ & $\begin{array}{l}\text { "The indicator measures the share of material recovered } \\
\text { and fed back into the economy - thus saving extraction of } \\
\text { primary raw materials - in overall material use" [21] }\end{array}$ & Eurostat \\
\hline & $\begin{array}{l}\text { Municipal waste's } \\
\text { recycling rate, } \%\end{array}$ & $\begin{array}{l}\text { "The indicator measures the share of recycled municipal } \\
\text { waste in the total municipal waste generation. Recycling } \\
\text { includes material recycling, composting and anaerobic } \\
\text { digestion" [21] }\end{array}$ & Eurostat \\
\hline
\end{tabular}

Note - compiled by authors.

Table 2 - Descriptive statistics

\begin{tabular}{|l|c|c|c|c|c|}
\hline \multicolumn{1}{|c|}{ Variable } & Observation & Mean & Std. Dev. & Min & Max \\
\hline $\begin{array}{l}\text { Generation of municipal waste per } \\
\text { capita }\end{array}$ & 27 & 512,11 & 128,79 & 280 & 844 \\
\hline Water exploitation index & 27 & 9,61 & 15,22 & 0,22 & 70,3 \\
\hline Final energy consumption & 27 & 34,41 & 49,47 & 0,7 & 214,5 \\
\hline Social Progress Index & 27 & 86,65 & 3,89 & 78,14 & 92,08 \\
\hline Circular material use rate & 27 & 9,37 & 7,14 & 1,3 & 30 \\
\hline Municipal waste's recycling rate & 27 & 39,5 & 14,82 & 8,9 & 66,7 \\
\hline Note- compiled by authors & & & & & \\
\hline
\end{tabular}

\section{Results and Discussion}

Table 3 - Circular economy efficiency of EU countries based on DEA

\begin{tabular}{|l|c|c|c|}
\hline Countries & Pure technical efficiency & Overall efficiency & Scale efficiency \\
\hline Belgium & 1 & 1 & 1 \\
\hline Estonia & 1 & 1 & 1 \\
\hline Germany & 1 & 1 & 1 \\
\hline Latvia & 1 & 1 & 1 \\
\hline Lithuania & 1 & 1 & 1 \\
\hline Malta & 1 & 1 & 1 \\
\hline Netherlands & 1 & 1 & 1 \\
\hline Slovenia & 1 & 1 & 0,978 \\
\hline Austria & 0,958 & 0,980 & 0,954 \\
\hline Luxembourg & 0,924 & 0,968 & 1 \\
\hline
\end{tabular}


MACROECONOMICS, WORLD ECONOMY

\begin{tabular}{|l|c|c|c|}
\hline Sweden & 0,883 & 0,999 & 0,884 \\
\hline Slovakia & 0,954 & 1 & 0,954 \\
\hline Italy & 0,895 & 1 & 0,895 \\
\hline Denmark & 0,826 & 0,922 & 0,896 \\
\hline Croatia & 0,821 & 1 & 0,821 \\
\hline Hungary & 0,78 & 1 & 0,78 \\
\hline Poland & 0,772 & 1 & 0,772 \\
\hline Bulgaria & 0,645 & 1 & 0,645 \\
\hline Finland & 0,736 & 0,905 & 0,814 \\
\hline France & 0,798 & 0,974 & 0,82 \\
\hline Cyprus & 0,645 & 0,972 & 0,663 \\
\hline Czech Republic & 0,574 & 0,938 & 0,612 \\
\hline Ireland & 0,617 & 0,899 & 0,686 \\
\hline Spain & 0,599 & 0,926 & 0,647 \\
\hline Greece & 0,363 & 0,934 & 0,388 \\
\hline Portugal & 0,484 & 0,904 & 0,536 \\
\hline Romania & 0,316 & 1 & 0,316 \\
\hline
\end{tabular}

Note - compiled by authors.

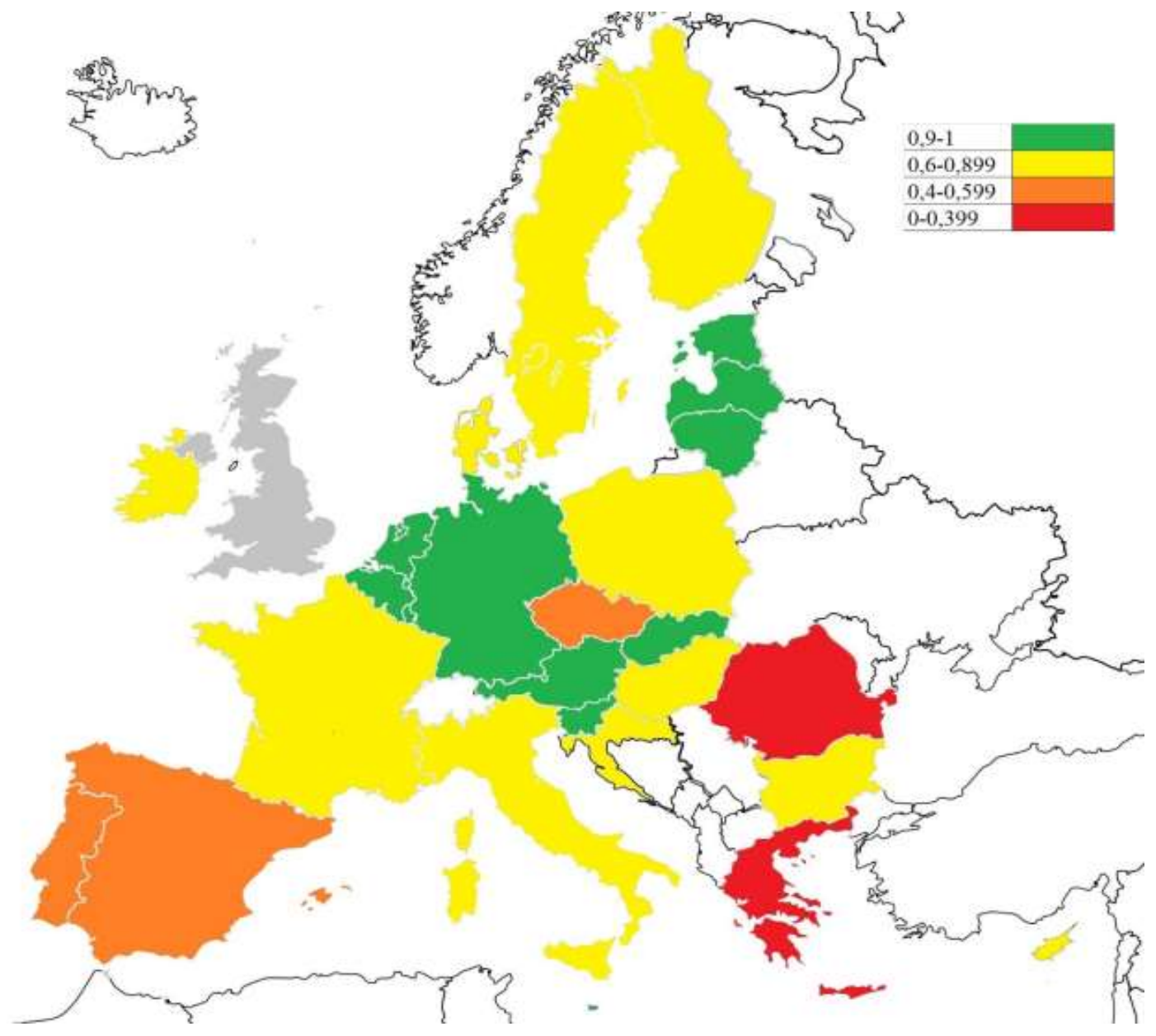

Figure 1 - Pure technical efficiency of circular economy's development in EU countries

Note - compiled by authors. 
Germany has the highest municipal waste's recycling rate $-66,7 \%$. The top 5 also includes Slovenia, Austria, Netherlands and Belgium. In the Baltic countries and Luxembourg, although the rate of waste recycling is lower (on average 42,6\%), there is a high efficiency of CE development, since final energy consumption is many times lower than in other countries - on average 4,25 million tons of oil equivalent. For comparison, this is 27 times less than in Italy (115,5 million tons of oil equivalent). Perhaps therefore Italy has a sufficient CE efficiency, given that more than half of municipal waste is recycled.

The low efficiency of CE of Romania and Greece is also justified: they produce less municipal waste but have a lower SPI score than the EU 27 average and show significantly lower municipal waste recycling rate and circular material use.

Table 3 indicates that the largest PTE is 1, and the lowest is 0,316 , with the average value being 0,8 . The average value is quite high, which indicates that the countries constructed a good economy-environment interaction nowadays.

Efficiency in CCR model of DEA of $27 \mathrm{EU}$ countries, which reflects both the current and future state of the circular economy advancement, show that all countries have positive trend of CE development. Because overall efficiency values of all 27 countries above than 0,9 , moreover 15 of them have value of $\mathrm{OE}$ equal to 1 , it's $55,6 \%$.

Noteworthy, that the main initiatives for progressing towards a circular economy are carried out at the macro level, that is, most of the efforts of the circular economy are modeled by governments and authorities at the local or regional levels. These macro-level initiatives are redefining production and consumption activities in general and contribute to the creation of a recycling-oriented society.
As mentioned earlier, "Action Plan for the Circular Economy" was adopted by the European Commission in 2015, which consisted of 54 actions. All these actions were being implemented by 2019 . The effectiveness results of the development of a circular economy using the DEA showed that these actions were indeed successfully implemented and the process of transition to a circular economy was launched. In general, the First Action Plan was aimed at widespread understanding and dissemination in society of the ideas of secondary consumption, waste management, shared economy, etc. In Europe, Germany was the first to introduce a dual waste collection system and a Closed-loop Substances and Waste Management Act. In Denmark, efforts have been focused on product design to drive change in business models and design strategies. This is done even for complex consumer products such as electronics or automobiles, or for manufacturing that uses modern technology. Many university-level research centers and EU-funded projects have focused on $\mathrm{CE}$, which has contributed to the spread of CE principles.

As for the implementation of actions, among the EU member states, the Netherlands and Sweden are leaders in terms of material efficiency, making a significant contribution to moving towards the circular economy. On the other hand, Italy, Spain, Luxembourg and Cyprus have heavily adapted sustainable production and consumption practices.

Detailed goals and actions have been defined in New action plan released in 2020 by European Commission. As a result of the implementation of 35 actions of this plan, it is planned to increase GDP by an additional $0,5 \%$ by 2030 and create about 700 thousand new jobs.

In particular, the new circular economy's action plan details the measures presented in Figure 2.

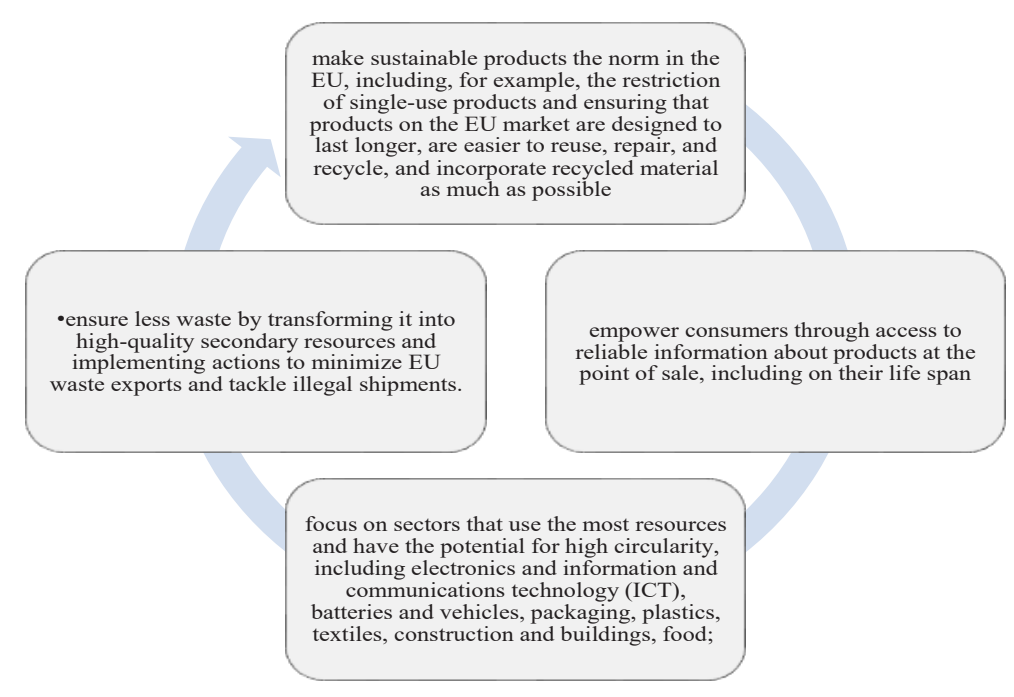

Figure 2 - Measures of New circular economy action plan 2020

Note - compiled by authors 
More detailed actions contribute to the progress of circularity in the future, as in the CCR model of Data Envelopment Analysis, that is, the achievement of high efficiency in all 27 countries of the EU.

\section{Conclusion}

The article's purpose was to assess the status quo and prospects for the circular economy's development in the countries of the EU. Using reliable data, through the Data Envelopment Analysis, a real assessment and the potential for converting to a circular economy were obtained.

In progressing towards circularity, all economic agents are stakeholders. Since, for the government, a circular economy contributes to an increase in GDP, new job creation, and an improving competitiveness. For companies, CE can increase their profitability through circular material use, protecting them from fluctuations in resource prices in the global market. For citizens, "the circular economy will provide high-quality, functional and safe products, which are efficient and affordable, last longer and are designed for reuse, repair, and high-quality recycling" [1].

The problem of waste recycling and the use of secondary resources has become especially relevant during the pandemic. COVID-19 highlighted the need to stop the destruction of the natural environment and exposed the fragility of the current economic model. The circular economy is a model for the future of Europe and the world. It brings balance back to nature and reduces vulnerability to disruptions in global complex supply chains. Circular production and consumption provide an opportunity to create a healthy and sustainable economy for future generations.

\section{References}

1. European Commission (2020). Circular Economy Action Plan: for a cleaner and more competitive Europe, 28 p.

2. Pearce, D., Turner, R.K. (1990). Economics of natural resources and the environment. Baltimore: Johns Hopkins University Press.

3. European Commission (2015). Circular Economy Action Plan.

4. Mhatre, P., Panchal, R., Singh, A., Bibyan, S. (2021). A systematic literature review on the circular economy initiatives in the European Union. Sustainable Production and Consumption, 26, 187-202. https://doi. org/10.1016/j.spc.2020.09.008

5. Friant, M.C., Vermeulen, W.J.V., Salomone, R. (2021). Analysing European Union circular economy policies: words versus actions. Sustainable Production and Consumption, 27, 337-353. https://doi. org/10.1016/j.spc.2020.11.001
6. Hartley, K., van Santen, R., Kirchherr, J. (2020). Policies for transitioning towards a circular economy: Expectations from the European Union (EU). Resources, Conservation and Recycling, 155, 104634. https://doi.org/10.1016/j.resconrec.2019.104634

7. Kirchherr, J., Piscicelli, L., Bour, R., KostenseSmit, E., Muller, J., Huibrechtse-Truijens, A., Hekkert, M. (2018). Barriers to the Circular Economy: Evidence From the European Union (EU). Ecological Economics, 150, pp. 264-272. https://doi.org/10.1016/j. ecolecon.2018.04.028

8. Momete, D. C. (2020). A unified framework for assessing the readiness of European Union economies to migrate to a circular modelling. Science of The Total Environment, 718, $137375 . \quad$ https://doi. org/10.1016/j.scitotenv.2020.137375

9. Marco-Fondevila, M., Llena-Macarulla, F., Callao-Gastón, S., Jarne-Jarne, J.I. (2021). Are circular economy policies actually reaching organizations? Evidence from the largest Spanish companies. Journal of Cleaner Production, 285, 124858. https://doi. org/10.1016/j.jclepro.2020.124858

10. Türkeli, S., Kemp, R., Huang ,B., Bleischwitz, R., McDowall, W. (2018). Circular economy scientific knowledge in the European Union and China: A bibliometric, network and survey analysis (2006-2016). Journal of Cleaner Production, 197(1), 1244-1261. https://doi.org/10.1016/j.jclepro.2018.06.118

11. Domingues Martinho, V.J.P. (2021). Insights into circular economy indicators: Emphasizing dimensions of sustainability. Environmental and Sustainability Indicators, 10, 100119. https://doi. org/10.1016/j.indic.2021.100119

12. Singh, S., Trivedi, D., Dasgupta, M.S., Routroy, S. (2021). A bibliometric analysis of circular economy concept in E-waste research during the period 2008-2020. Materialstoday: proceedings. https://doi.org/10.1016/j.matpr.2021.03.525

13. Awasthi, A.K., Cucchiella F., D’Adamo, I., Li, J., Rosa, P., Terzi, S., Wei, G., Zeng ,X. (2018). Modelling the correlations of e-waste quantity with economic increase. Science of The Total Environment, 613-614, 46-53. https://doi.org/10.1016/j.scitotenv.2017.08.288

14. Hadzic, A., Voca, N., Golubic, S. (2018). Life-cycle assessment of solid-waste management in city of Zagreb, Croatia. The Journal of Material Cycles and Waste Management, 20, 1286-1298. https://doi. org/10.1007/s10163-017-0693-2

15. Martin, M., Wetterlund, E., Hackl, R., Holmgren, K.M., Peck, P. (2017). Assessing the aggregated environmental benefits from by-product and utility synergies in the Swedish biofuel industry. Biofuels, 11(6), 683-698. https://doi.org/10.1080/1759 7269.2017.1387752

16. Exposito, A., Velasco, F. (2018). Municipal solid-waste recycling market and the European 2020 Horizon Strategy: A regional efficiency analysis in Spain. Journal of Cleaner Production, 172, 938-948. https://doi.org/10.1016/j.jclepro.2017.10.221

17. Voskamp, I. M., Stremke, S., Spiller, M., Perrotti, D., van der Hoek, J.P., Rijnaarts, H.H.M. (2016). Enhanced performance of the eurostat method for comprehensive assessment of urban metabolism: 
a material flow analysis of Amsterdam. Journal of Industrial Ecology, 21(4), 887-902. https://doi. org/10.1111/jiec. 12461

18. Charnes, A., Cooper, W.W., Rhodes, E. (1978). Measuring the efficiency of decision-making units. European Journal of Operational Research, 2(6), 429444. https://doi.org/10.1016/0377-2217(78)90138-8

19. Banker, R.D., Charnes, A., Cooper, W.W. (1984). Some models for estimating technical and scale efficiencies in data envelopment analysis. Management Science, 30(9), 1078-1093. https://doi.org/10.1287/ mnsc. 30.9.1078

20. Fan, Y., Fang, C. (2020). Circular economy development in China-current situation, evaluation and policy implications. Environmental Impact Assessment Review, 84, 106441. $\quad$ https://doi.org/10.1016/j. eiar.2020.106441

21. European Comission. Eurostat database https://ec.europa.eu/eurostat/web/main/data/database

22. Social Progress Imperative website https:// www.socialprogress.org/

\section{Information about the authors}

Zhansaya S. Temerbulatova - PhD, Al-Farabi Kazakh National University, Kazahstan, e-mail: t.zhansaya.s@mail. ru. ORCID ID: https://orcid.org/0000-0002-3205-0948

* Aknur Zhidebekkyzy - PhD, Associate Professor, Al-Farabi Kazakh National University, Kazahstan, e-mail: aknur. zh@gmail.com, ORCID ID: https://orcid.org/0000-0003-3543-547X

Monika Grabowska - PhD, Wroclaw University of Economics and Business, Wroclaw, Poland, e-mail: $\underline{\text { monika. }}$ grabowska@ue.wroc.pl. ORCID ID: https://orcid.org/0000-0001-9627-0221

\section{Авторлар туралы мәліметтер}

Темербулатова Ж.С. - PhD докторы, әл-Фараби атындағы Қазақ ұлттық университеті, Қазақстан, е-таil: t.zhansaya.s@mail.ru. ORCID ID: https://orcid.org/0000-0002-3205-0948

* Жидебекқызы A. - PhD докторы, қауымдастырылған профессор, әл-Фараби атындағы Қазақ ұлттық университеті, Қазақстан, e-mail: aknur.zh@gmail.com, ORCID ID: https://orcid.org/0000-0003-3543-547X

Грабовска М. - PhD докторы, Вроцлав экономика және бизнес университеті, Вроцлав қ., Польша, е-таil: monika.grabowska@ue.wroc.pl. ORCID ID: https://orcid.org/0000-0001-9627-0221

\section{Сведения об авторах}

Темербулатова Ж.С. - PhD, КазНУ им. аль-Фараби, Казахстан, e-mail: t.zhansaya.s@mail.ru. ORCID ID: https://orcid.org/0000-0002-3205-0948

* Жидебекқызы А. - PhD, ассоциированный профессор, КазНУ имени аль-Фараби, Казахстан, e-mail: aknur. zh@gmail.com, ORCID ID: https://orcid.org/0000-0003-3543-547X

Грабовска М. - PhD, Университет экономики и бизнеса во Вроцлаве, г. Вроцлав, Польша, е-mail: monika. grabowska@ue.wroc.pl. ORCID ID: https://orcid.org/0000-0001-9627-0221 